\section{A New Type of Doubly Silylamido-Bridged Cyclopentadienyl Group 4 Metal Complexes**}

Jesús Cano, Pascual Royo,* Maurizio Lanfranchi, Maria Angela Pellinghelli, and Antonio Tiripicchio

Dedicated to Professor Rafael Usón

on the occasion of his 75th birthday

The isolation of metal complexes containing the $\eta^{1}$-amidosilyl- $\eta^{5}$-cyclopentadienyl ligand, which provides more acidic metal centers with a more open coordination site than the ansa-dicyclopentadienyl compounds, has proved particularly useful. ${ }^{[1]}$ These structural features are responsible for their catalytic ability to copolymerize long-chain $\alpha$-olefins. ${ }^{[2]} \mathrm{Nu}$ merous contributions in this field have benefited from the research into the use of variously substituted ligands, ${ }^{[3]}$ the characterization of the active cationic species, ${ }^{[4]}$ the development of new industrial applications, ${ }^{[5]}$ and the reactivity of the metal-coordinated amidosilyl moiety. ${ }^{[6]}$

Few examples of doubly bridged $\eta^{5}$-cyclopentadienyl-di $\left(\eta^{1}\right.$ ligand) metal compounds have been reported. ${ }^{[7]}$ We have now extended our studies in this field by synthesizing new substituted cyclopentadienyl ligands that can form more than one amidosilyl bridge, that is $\operatorname{di}(\eta$-amidosilyl $)-\eta^{5}$-cyclopentadienyl ligands, and characterizing and studying the reactivity of their Group 4 metal complexes.

The di(amidosilyl)cyclopentadiene $\mathrm{C}_{5} \mathrm{H}_{4}\left[\mathrm{SiMe}_{2}(\mathrm{NH} t \mathrm{Bu})\right]_{2}$ (1) was synthesized as a yellow oil from $1,1-\left(\mathrm{SiMe}_{2} \mathrm{Cl}\right)_{2} \mathrm{C}_{5} \mathrm{H}_{4}{ }^{[8]}$ and $\mathrm{LiNH} t \mathrm{Bu}$ in $12 \mathrm{~h}$ at room temperature using THF as solvent. Selective deprotonation of the more acidic cyclopentadiene proton and only one of the amino protons of $\mathbf{1}$ by using $\left[\mathrm{Zr}\left(\mathrm{NMe}_{2}\right)_{4}\right]$ afforded the monosilylamido derivative $\mathbf{2}$ as a light-brown oil (Scheme 1 ). $\mathrm{A} \mathrm{C}_{6} \mathrm{D}_{6}$ solution of $\mathbf{2}$ was heated to $110^{\circ} \mathrm{C}$ to give the disilylamido compound $\mathbf{3}$ with evolution of $\mathrm{NHMe}_{2}$. However this reaction was reversed when the mixture was cooled to room temperature, preventing the isolation of $\mathbf{3}$. Similar deprotonation of $\mathbf{1}$ by using the tetrabenzyl compound $\left[\mathrm{Zr}\left(\mathrm{CH}_{2} \mathrm{Ph}\right)_{4}\right]$, gave a mixture of the brown monosilylamido 4, identified by ${ }^{1} \mathrm{H}$ NMR spectroscopy, and the disilylamido derivative $\mathbf{5}$ at room temperature (Scheme 1), while $\mathbf{5}$ was the unique reaction product at

[*] Prof. Dr. P. Royo, J. Cano

Departamento de Química Inorgánica

Facultad de Ciencias, Universidad de Alcalá

Campus Universitario, 28871 Alcalá de Henares (Spain)

Fax: (+34) 91-8854683

E-mail: pascual.royo@uah.es

Prof. Dr. M. Lanfranchi, Prof. Dr. M. A. Pellinghelli,

Prof. Dr. A. Tiripicchio

Dipartimento di Chimica Generale ed Inorganica

Chimica Analitica, Chimica Fisica

Università di Parma, Centro di Studio per la Strutturistica Diffrattometrica del CNR

Parco Area delle Scienze 17 A, 43100 Parma (Italy)

[**] We thank the Dirección General de Enseñanza Superior e Investigación Científica (DGESEIC) for financial support of this work (Project PB97-0776). J.C. thanks the CAM for a Postgraduate Fellowship.

Supporting information for this article is available on the WWW under http://www.angewandte.com or from the author.

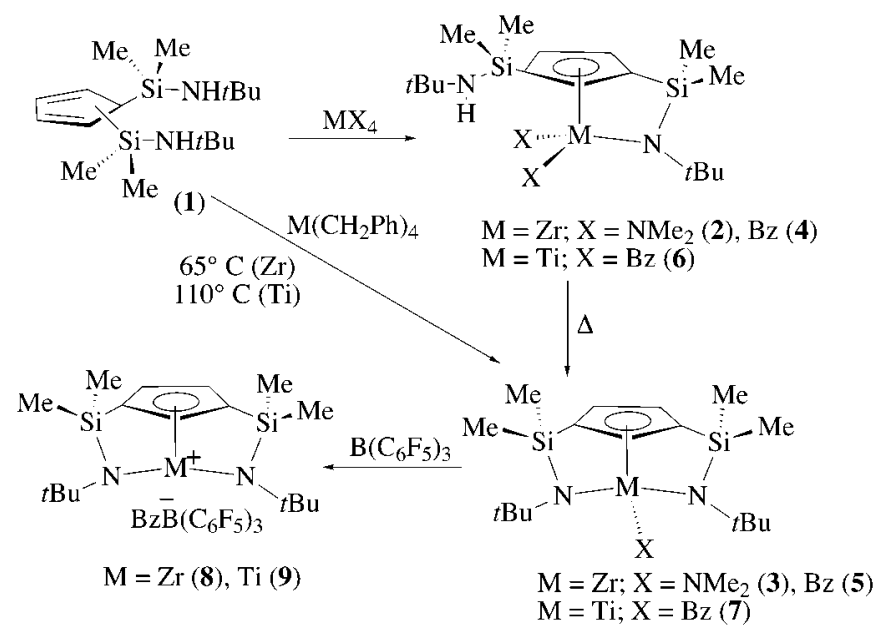

Scheme 1. Synthesis of neutral bridged $\eta^{5}$-cyclopentadienyl mono- and $\operatorname{di}(\eta$-amidosilyl)titanium and -zirconium complexes and their cationic species.

temperatures higher than $65^{\circ} \mathrm{C}$. The deprotonating capacity of complex 5 facilitated the irreversible transformation of $\mathbf{2}$ into 3 by elimination of the $\mathrm{NHMe}_{2}$ resulting from that transformation. A similar reaction of $\mathbf{1}$ with $\left[\mathrm{Ti}\left(\mathrm{CH}_{2} \mathrm{Ph}\right)_{4}\right]$ gave the monosilylamido complex $\mathbf{6}$ as a red solid, which could only be transformed into the disilylamido derivative 7 by refluxing a solution of the compound in toluene.

All the new compounds were characterized by elemental analyses, and the ${ }^{1} \mathrm{H}$ and ${ }^{13} \mathrm{C}$ NMR spectra were consistent (see Supporting Information) with the asymmetry of the monosilylamido compounds $\mathbf{2}, \mathbf{4}$, and $\mathbf{6}$, and with the presence of a plane of symmetry in the disilylamido compounds $\mathbf{3}, \mathbf{5}$, and 7 (Scheme 1). The chemical shifts of the $t$ Bu tertiary carbon atoms were observed between $\delta=55.8(\mathbf{3})$ and $\delta=61.5$ (6) for bridged, and between $\delta=49.6$ (2) and $\delta=49.8$ (6) for unbridged amidosilyl groups; the $\Delta \delta$ values ${ }^{[9]}$ were between 20.2 and 27.2 for bridged and between 15.7 and 16.0 for unbridged amidosilyl groups, respectively. Treatment of solutions of 5 and 7 in toluene with one equivalent of $\mathrm{B}\left(\mathrm{C}_{6} \mathrm{~F}_{5}\right)_{3}$ gave the complexes $\mathbf{8}$ and $\mathbf{9}$, respectively (Scheme 1 ). The ${ }^{1} \mathrm{H},{ }^{13} \mathrm{C}$, and ${ }^{19} \mathrm{~F}$ NMR spectra of 8 and 9 in $\mathrm{C}_{6} \mathrm{D}_{6}$ were consistent with their formulation as the salts of $C_{\mathrm{s}}$-symmetric base-free cations and the $\left[\left(\mathrm{CH}_{2} \mathrm{Ph}\right) \mathrm{B}\left(\mathrm{C}_{6} \mathrm{~F}_{5}\right)_{3}\right]^{-}$ion..$^{[10,11]}$

Crystals of 9 suitable for a single-crystal X-ray structure determination were grown by cooling a saturated solution of 9 in benzene. The structure of $\mathbf{9}$ (Figure 1) shows a titanium cation with the centroid of the cyclopentadienyl ring and the two amido-N atoms occupying three positions in a pseudotetrahedral ligand arrangement, the fourth position being occupied by the "meta-C-H bond" or alternatively by a "meta-C atom" of the phenyl ring of the benzylborate anion. The $\eta^{5}$-cyclopentadienyl di $(\eta$-amidosilyl $)$ ligand shows a strongly constrained geometry, which allows it to interact with the metal as a tridentate ligand; the $\mathrm{C} 1$ and $\mathrm{C} 3$ atoms that bear the amidosilyl arms are pyramidally distorted, as shown by the sums of the bond angles $\left(348.0^{\circ}\right.$ and $348.1^{\circ}$, respectively). The Ti-N and the Ti-CE1 (CE1 is the Cp centroid) distances are similar to those observed in related neutral amidosilylcyclopentadienyl compounds. ${ }^{[\mathrm{d}]}$ The $\mathrm{Ti}-\mathrm{C} 21$ dis- 


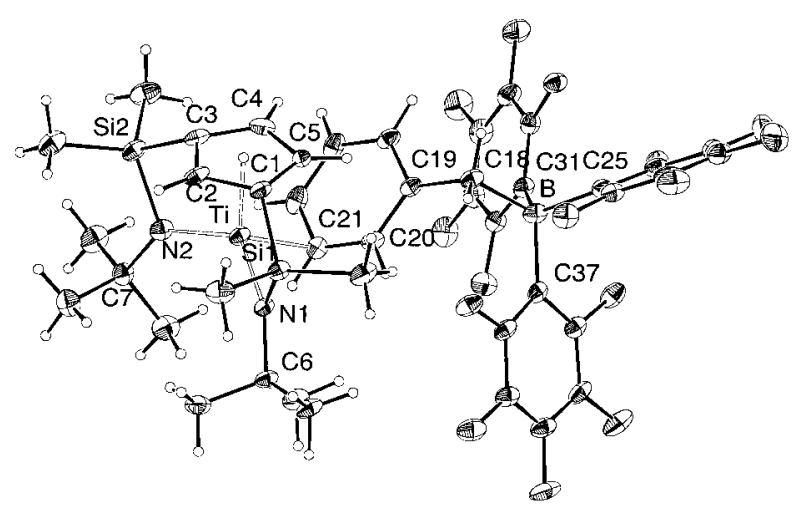

Figure 1. Molecular structure of $\mathbf{9}$ (the ellipsoids for the atoms are drawn at $30 \%$ probability level). Selected interatomic distances [ $[\AA]$ and angles $\left[{ }^{\circ}\right]$ : Ti-CE1 1.997(5), Ti-N1 1.959(4), Ti-N2 1.946(5), Ti-C21 2.447(6), Ti-M1 2.33, Ti-H21 2.30; N1-Ti-N2 126.3(2), CE1-Ti-N1 106.7(2), CE1-Ti-N2 106.6(2), CE1-Ti-M1 129.5(3), N1-Ti-M1 95.0(3), N2-Ti-M1 95.0(3); CE1 and $\mathrm{M} 1$ are the centroid of the $\mathrm{Cp}$ ring and the midpoint of the $\mathrm{C} 21-\mathrm{H}$ bond, respectively.

tance ( $\mathrm{Ti}-\mathrm{C} 212.447(6) \AA)$ is about $0.3 \AA$ longer than that normally expected for covalent $\mathrm{Ti}-\mathrm{C} \sigma$ bonds. The interaction with the electron pair in the $\mathrm{C}-\mathrm{H}$ bond is consistent with the distances observed from $\mathrm{Ti}$ to $\mathrm{H} 21$ and to the middle of the $\mathrm{C}-\mathrm{H}$ bond (M1) (Ti-H21 2.30, Ti-M1 $2.33 \AA$ ). Metal $-\eta^{6}-$ phenyl, ${ }^{[11,12]}$ metal $-\eta^{5}$-phenyl, ${ }^{[13]}$ and metal $-\eta^{3}$-phenyl ${ }^{[14]}$ interactions for related benzylborate anions have been reported but, as far as we are aware, there have been no reports of this type of interaction in which a single meta- $\mathrm{C}_{\text {phenyl }}-\mathrm{H}$ bond of the benzylborate anion interacts with the empty hybrid metal orbital of a typical "three leg piano stool" coordination. Furthermore, the alternative interaction with the $\mathrm{p}$ orbital of the $m e t a-\mathrm{C}_{\text {phenyl }}$ atom similar to that found for $\eta^{1}$-benzenecoordinated silver compounds ${ }^{[15]}$ cannot be ignored.

Compound $\mathbf{8}$ polymerizes ethylene at room temperature and pressure ${ }^{[16]}$ despite being free of alkyl ligands. Immediate polymerization was observed when a teflon-valved Schlenk tube containing 8 was evacuated and filled with ethylene. The polymerization activity of compound $\mathbf{5}$ was measured by using a solution containing methylaluminoxane (MAO; $19.3 \mathrm{mmol}$ ) and $5(4.2 \mu \mathrm{mol})$ in $n$-hexane $(600 \mathrm{~mL})$ at 4 atm ethylene and $70^{\circ} \mathrm{C}$. The observed activity after $15 \mathrm{~min}$ was $7.4 \times$ $10^{5} \mathrm{gPE}(\mathrm{molZr})^{-1} \mathrm{~h}^{-1} \mathrm{~atm}^{-1}$. The polyethylene (PE) produced showed a very high molecular weight $\left(M_{\mathrm{w}}=5.4 \times 10^{5}\right)$ with a polydispersity index $M_{\mathrm{w}} / M_{\mathrm{n}}$ of 1.9 . It was insoluble in 1,2,4-trichlorobenzene preventing its characterization by NMR spectroscopy. Compound $\mathbf{5}$ was also an active catalyst for the copolymerization of ethylene and 1-hexene. When the same experiment was carried out under the same conditions but with the prior addition of 1-hexene $(10 \mathrm{~mL})$, the resulting polymer $\left(M_{\mathrm{w}}=4.1 \times 10^{5}\right.$ and $\left.M_{\mathrm{w}} / M_{\mathrm{n}}=2.2\right)$ after $30 \mathrm{~min}$ contained $0.7 \mathrm{~mol} \%$ of 1 -hexene and the catalytic activity was $3.5 \times 10^{5}$ g polymer $(\mathrm{mol} \mathrm{Zr})^{-1} \mathrm{~h}^{-1} \mathrm{~atm}^{-1}$.

\section{Experimental Section}

Full experimental details, analytical data and NMR assignments for all compounds are provided as Supporting Information.

Representative procedure: A solution of $\left[\mathrm{Ti}\left(\mathrm{CH}_{2} \mathrm{Ph}\right)_{4}\right](2.14 \mathrm{~g}, 5.2 \mathrm{mmol})$ in toluene $\left(70 \mathrm{~mL}\right.$ ) was cooled to $0^{\circ} \mathrm{C}$, and an equimolar amount of $\mathbf{1}$ was added by syringe. The resulting yellow solution was warmed for $5 \mathrm{~h}$ to $65^{\circ} \mathrm{C}$. The solvent was removed under vacuum and the residue was extracted into pentane $(70 \mathrm{~mL})$. After filtration and removal of the solvent, complex 6 was isolated as a red solid $(2.87 \mathrm{~g}, 5.2 \mathrm{mmol}, 100 \%)$.

A similar reaction carried out under reflux gave complex 7 (5.93 g, $12.9 \mathrm{mmol}, 100 \%$ ) as a dark red solid.

A solution of the monobenzyl complex $7(0.116 \mathrm{~g}, 0.25 \mathrm{mmol})$ in toluene $(20 \mathrm{~mL})$ was treated with $\mathrm{B}\left(\mathrm{C}_{6} \mathrm{~F}_{5}\right)_{3}(0.126 \mathrm{~g}, 0.25 \mathrm{mmol})$ at room temperature and the mixture was stirred for $30 \mathrm{~min}$ and then cooled to $-35^{\circ} \mathrm{C}$. The solvent was filtered off from the resulting insoluble residues, which were then dried under vacuum to give $9(0.13 \mathrm{~g}, 60 \%$ yield $)$ as an orange crystalline solid. An appropriate monocrystal of 9 was separated for study using X-ray diffraction methods.

${ }^{1} \mathrm{H}$ NMR (300 MHz, $\mathrm{C}_{6} \mathrm{D}_{6}, 20^{\circ} \mathrm{C}$, TMS) for $6: \delta=0.21,0.27(2 \mathrm{~s}, 2 \times 3 \mathrm{H}$; $\left.\mathrm{Si} M e_{2} \mathrm{NH} t \mathrm{Bu}\right), 0.37,0.38\left(2 \mathrm{~s}, 2 \times 3 \mathrm{H} ; \mathrm{Si} M e_{2} \mathrm{~N} t \mathrm{Bu}\right), 0.72(\mathrm{~s}, 1 \mathrm{H} ; \mathrm{NH} t \mathrm{Bu}) 1.07$ $(\mathrm{s}, 9 \mathrm{H} ; \mathrm{NH} t \mathrm{Bu}), 1.44$ (s, 9H; NtBu) $2.47,2.55,2.81,2.97(4 \mathrm{~d}, J=10.5 \mathrm{~Hz}$, $\left.4 \times 1 \mathrm{H} ; \mathrm{CH}_{2} \mathrm{Ph}\right), 5.83,6.14,6.83\left(3 \mathrm{~m}, 3 \times 1 \mathrm{H} ; \mathrm{C}_{5} \mathrm{H}_{3}\right), 6.87-7.20(\mathrm{~m}, 10 \mathrm{H}$; $\left.\mathrm{CH}_{2} P h\right) ;{ }^{13} \mathrm{C}$ NMR $\left(300 \mathrm{MHz}, \mathrm{C}_{6} \mathrm{D}_{6}, 20^{\circ} \mathrm{C}, \mathrm{TMS}\right): \delta=0.6,1.5\left(\mathrm{SiMe}_{2} \mathrm{NH}-\right.$ $t \mathrm{Bu}), 2.4,2.9\left(\mathrm{Si} M e_{2} \mathrm{~N} t \mathrm{Bu}\right), 33.8(\mathrm{NH} t \mathrm{Bu}), 34.3(\mathrm{~N} t \mathrm{Bu}), 49.8\left(\mathrm{NH} t \mathrm{Bu}_{i p s o}\right), 61.5$ $\left(\mathrm{N} t \mathrm{Bu}_{\text {ipso }}\right), 79.6,83.7\left(\mathrm{CH}_{2} \mathrm{Ph}\right), 110.2,122.8\left(\mathrm{C}_{5} \mathrm{H}_{3 i p s o}\right), 122.1,122.5,123.0$ $\left(\mathrm{C}_{5} \mathrm{H}_{3}\right), 125.9$ 126.8, 126.8, 127.4, 128.5, 128.6, 128.7, 128.9, 129.8, 132.6 $\left(\mathrm{C}_{6} \mathrm{H}_{5}\right), 149.6,150.1\left(\mathrm{C}_{6} \mathrm{H}_{5 i p s o}\right)$; elemental analysis for 6: calcd: $\mathrm{C} 62.68, \mathrm{H}$ 8.68, N 5.76; found: C 62.58, H 8.75, N 6.08.

${ }^{1} \mathrm{H}$ NMR $\left(300 \mathrm{MHz}, \mathrm{C}_{6} \mathrm{D}_{6}, 20^{\circ} \mathrm{C}\right.$, TMS) for 7: $\delta=0.39,0.40(2 \mathrm{~s}, 2 \times 6 \mathrm{H}$; $\left.\mathrm{SiMe}_{2}\right), 1.42(\mathrm{~s}, 18 \mathrm{H} ; \mathrm{N} t \mathrm{Bu}), 2.61\left(\mathrm{~s}, 2 \mathrm{H} ; \mathrm{CH}_{2} \mathrm{Ph}\right), 6.14\left(\mathrm{~d}, 2 \mathrm{H} ; \mathrm{C}_{5} \mathrm{H}_{3}\right), 6.40$ $\left(\mathrm{t}, 1 \mathrm{H} ; \mathrm{C}_{5} \mathrm{H}_{3}\right), 6.89\left(\mathrm{~m}, 1 \mathrm{H} ; \mathrm{C}_{6} \mathrm{H}_{5}\right), 7.00\left(\mathrm{~m}, 2 \mathrm{H} ; \mathrm{C}_{6} \mathrm{H}_{5}\right), 7.22\left(\mathrm{~m}, 2 \mathrm{H} ; \mathrm{C}_{6} \mathrm{H}_{5}\right)$; ${ }^{13} \mathrm{C} \mathrm{NMR}\left(300 \mathrm{MHz}, \mathrm{C}_{6} \mathrm{D}_{6}, 20{ }^{\circ} \mathrm{C}, \mathrm{TMS}\right): \delta=2.1,2.2\left(\mathrm{SiMe}_{2}\right), 35.6(\mathrm{~N} t \mathrm{Bu})$, $59.3\left(\mathrm{~N} t \mathrm{Bu}_{\text {ipso }}\right), 69.6\left(\mathrm{CH}_{2} \mathrm{Ph}\right), 117.7\left(\mathrm{C}_{5} \mathrm{H}_{3 i p s o}\right), 121.5,126.3\left(\mathrm{C}_{5} \mathrm{H}_{3}\right), 128.5$, 130.3, $132.6\left(\mathrm{C}_{6} \mathrm{H}_{5}\right), 152.4\left(\mathrm{C}_{6} \mathrm{H}_{5 i p s o}\right)$; elemental analysis for 7: calcd: $\mathrm{C} 67.82$, H 8.71, N 4.81; found: C 67.36, H 8.75, N 5.07.

${ }^{1} \mathrm{H}$ NMR (300 MHz, $\mathrm{C}_{6} \mathrm{D}_{6}, 20^{\circ} \mathrm{C}$, TMS) for 9: $\delta=0.19,0.38(2 \mathrm{~s}, 2 \times 6 \mathrm{H}$; $\left.\mathrm{SiMe}_{2}\right), 1.12$ (s, $\left.18 \mathrm{H} ; \mathrm{N} t \mathrm{Bu}\right), 3.49\left(\mathrm{~s}, 2 \mathrm{H} ; \mathrm{BCH}_{2}\right), 5.03\left(\mathrm{~m}, 1 \mathrm{H} ; \mathrm{C}_{5} \mathrm{H}_{3}\right), 5.86$ $\left(\mathrm{m}, 2 \mathrm{H} ; \mathrm{C}_{5} \mathrm{H}_{3}\right), 6.21-7.10\left(\mathrm{~m}, 5 \mathrm{H} ; \mathrm{C}_{6} \mathrm{H}_{5}\right) ;{ }^{13} \mathrm{C} \mathrm{NMR}\left(300 \mathrm{MHz}, \mathrm{C}_{6} \mathrm{D}_{6}, 20{ }^{\circ} \mathrm{C}\right.$, TMS $): \delta=0.6,1.4\left(\mathrm{SiMe}_{2}\right), 34.6(\mathrm{~N} t \mathrm{Bu}), 59.3\left(\mathrm{~N} t \mathrm{Bu}_{i p s o}\right), 122.1,126.2\left(\mathrm{C}_{5} \mathrm{H}_{3}\right)$, $126.1\left(\mathrm{C}_{5} \mathrm{H}_{3 i p s o}\right), 128.3,128.7,132.9\left(\mathrm{C}_{6} \mathrm{H}_{5}\right), 135.1,140.1,145.8,150.9\left(C_{6} \mathrm{~F}_{5}\right)$; ${ }^{19} \mathrm{~F}$ NMR $\left(300 \mathrm{MHz}, \mathrm{C}_{6} \mathrm{D}_{6}, 20{ }^{\circ} \mathrm{C}, \mathrm{CCl}_{3} \mathrm{~F}\right): \delta=132.1\left(\mathrm{~m}, 2 \mathrm{~F} ; o-\mathrm{C}_{6} \mathrm{~F}_{5}\right), 163.6$ $\left(\mathrm{m}, 1 \mathrm{~F} ; p-\mathrm{C}_{6} \mathrm{~F}_{5}\right), 167.2\left(\mathrm{~m}, 2 \mathrm{~F} ; m-\mathrm{C}_{6} \mathrm{~F}_{5}\right)$.

Crystal data of $9\left(\mathrm{C}_{42} \mathrm{H}_{40} \mathrm{BF}_{15} \mathrm{~N}_{2} \mathrm{Si}_{2} \mathrm{Ti}, M_{\mathrm{r}}=972.65\right): T=173(2) \mathrm{K}, \lambda=$ $1.54184 \AA$; triclinic, space group $P \overline{1}$, unit cell dimensions, $a=11.564(6)$, $b=13.531(6), c=14.020(7) \AA, \alpha=78.32(2), \beta=87.64(2), \gamma=87.01(2)^{\circ}, V=$ $2144.3(18) \AA^{3} ; Z=2 ; \rho_{\text {calcd }}=1.506 \mathrm{~g} \mathrm{~cm}^{-3} ; \mu=3.124 \mathrm{~mm}^{-1}, F(000)=992$, crystal size $0.42 \times 0.38 \times 0.25 \mathrm{~mm}, \theta$ range $3.22-69.99^{\circ}$. Reflections collected and unique 8113, observed $4019[I>2 \sigma(I)]$. Full-matrix leastsquares refinement on $F^{2},{ }^{[17]} 578$ parameters, hydrogen atoms introduced in the geometrically calculated positions and refined riding on the parent atoms, goodness-of-fit on $F^{2} 0.877$. Final $R$ indices $[I>2 \sigma(I)], R 1=0.0665$, $w R 2=0.1634, R$ indices (all data) $R 1=0.1349, w R 2=0.2051$. Crystallographic data (excluding structure factors) for the structure reported in this paper have been deposited with the Cambridge Crystallographic Data Centre as supplementary publication no. CCDC-152472. Copies of the data can be obtained free of charge on application to CCDC, 12 Union Road, Cambridge CB21EZ, UK (fax: (+44)1223-336-033; e-mail: deposit@ccdc. cam.ac.uk).

Received: January 22, 2001 [Z16465]

[1] a) P. J. Shapiro, E. E. Bunel, W. E. Piers, J. E. Bercaw, Synlett 1990, 2, 74 ; b) P. J. Shapiro, E. Bunel, W. P. Schaefer, J. E. Bercaw, Organometallics 1990, 9, 867; c) J. Okuda, Chem. Ber. 1990, 123, 1649; d) P. J. Shapiro, W. E. Cotter, W. P. Schaefer, J. A. Labinger, J. E. Bercaw, J. Am. Chem. Soc. 1994, 116, 4623.

[2] a) P. C. Möhring, N. J. Coville, J. Organomet. Chem. 1994, 479, 1; b) H. H. Brintzinger, D. Fischer, R. Mülhaupt, B. Rieger, R. M. Waymouth, Angew. Chem. 1995, 107, 1255; Angew. Chem. Int. Ed. Engl. 1995, 34, 1143; (corrigendum: H. H. Brintzinger, D. Fischer, R. Mülhaupt, B. Rieger, R. M. Waymouth, Angew. Chem. 1995, 107, 1652; Angew. Chem. Int. Ed. Engl. 1995, 34, 1368); c) A. L. Mcknight, R. M. Waymouth, Chem. Rev. 1998, 98, 2587; d) W. Kaminsky, J. Chem. Soc. Dalton Trans. 1998, 1413; e) G. G. Hlatky, Coord. Chem. Rev. 1999, 181, 256. 
[3] a) A. K. Hughes, A. Meetsma, J. H. Teuben, Organometallics 1993, 12, 1936; b) W. A. Herrmann, M. J. A. Morawietz, J. Organomet. Chem. 1994, 482, 169; c) J. Okuda, F. J. Schattenmann, S. Wocadlo, W. Massa, Organometallics 1995, 14, 789; d) D. W. Carpenetti, L. Kloppenburg, J. T. Kupec, J. L. Petersen, Organometallics 1996, 15, 1572; e) S. Ciruelos, T. Cuenca, R. Gómez, P. Gómez-Sal, A. Manzanero, P. Royo, Organometallics 1996, 15, 5577; f) R. Gómez, P. Gómez-Sal, A. Martín, A. Núñez, P. A. del Real, P. Royo, J. Organomet. Chem. 1998, 564, 93; g) B. Royo, P. Royo, L. M. Cadenas, J. Organomet. Chem. 1998, 551, 293; h) T. Eberle, T. P. Spaniol, J. Okuda, Eur. J. Inorg. Chem. 1998, 237; i) L. Duda, G. Erker, R. Fröhlich, F. Zippel, Eur. J. Inorg. Chem. 1998, 1153; j) D. Kunz, G. Erker, R. Fröhlich, G. Kehr, Eur. J. Inorg. Chem. 2000, 409.

[4] a) M. Bochmann, J. Chem. Soc. Dalton Trans. 1996, 255; b) Y.-X. Chen, P.-F. Fu, C. L. Stern, T. J. Marks, Organometallics 1997, 16, 5958; c) B. E. Bosch, G. Erker, R. Fröhlich, O. Meyer, Organometallics 1997, 16, 5449; d) Y.-X. Chen, T. J. Marks, Organometallics 1997, 16, 3649; e) A. Bertuleit, C. Fritze, G. Erker, R. Fröhlich, Organometallics 1997, 16, 2891; f) G. Lanza, I. L. Fragalà, T. J. Marks, J. Am. Chem. Soc. 1998, 120, 8257; g) F. Amor, A. Butt, K. E. Du Plooy, T. B. Spaniol, J. Okuda, Organometallics 1998, 17, 5836; h) R. Gómez, P. Gómez-Sal, P. A. del Real, P. Royo, J. Organomet. Chem. 1999, 588, 22.

[5] a) J. C. Stevens, F. J. Timmers, D. R. Wilson, G. F. Schmidt, P. N. Nickias, R. K. Rosen, G. W. Knight, S. Lai (Dow), EP 416815, 1991 [Chem. Abstr. 1991, 115, 93163]; b) J. M. Canich (Exxon), EP 420436, 1991 [Chem. Abstr. 1991, 115, 184145].

[6] a) P. Jutzi, U. Siemeling, J. Organomet. Chem. 1995, 500, 175; b) P. Jutzi, T. Redeker, Eur. J. Inorg. Chem. 1998, 663; c) T. Cuenca, P. Royo, Coord. Chem. Rev. 1999, $193-195,447$; d) R. Kempe, Angew. Chem. 2000, 112, 478; Angew. Chem. Int. Ed. 2000, 39, 468; e) L. H. Gade, Chem. Commun. 2000, 173.

[7] a) M. D. Fryzuk, S. S. S. H. Mao, P. B. Duval, S. J. Rettig, Polyhedron 1995, 14, 11; b) M. D. Fryzuk, L. Jafarpour, Organometallics 1999, 18, 4050; c) M. D. Fryzuk, P. B. Duval, S. S. S. H. Mao, M. J. Zaworotko, L. R. MacGillivray, J. Am. Chem. Soc. 1999, 121, 2478; d) I. L. Feduskin, S. Dachert, H. Schuman, Organometallics 2000, 19, 4066; e) P. Doufou, K. A. Abboud, J. M. Boncella, J. Organomet. Chem. 2000, 603, 213.

[8] J. M. Rozell, P. R. Jones, Organometallics 1985, 4, 2206.

[9] a) W. A. Nugent, B. L. Haymore, Coord. Chem. Rev. 1980, 31, 123; b) D. E. Wigley, Prog. Inorg. Chem. 1994, 42, 239; c) M. J. Humphries, M. L. H. Green, M. A. Leech, V. C. Gibson, M. Jolly, D. N. Williams, M. R. J. Elsegood, W. Clegg, J. Chem. Soc. Dalton Trans. 2000, 4044.

[10] A. D. Horton, J. de With, Chem. Commun. 1996, 1375.

[11] No phenyl coordination of the phenyl ring to the metal was observed in solution: C. Pellecchia, A. Grassi, A. Immirzi, J. Am. Chem. Soc. 1993, 115, 1160 .

[12] a) M. G. Thorn, Z. C. Etheridge, P. E. Fanwick, I. P. Rothwell, Organometallics 1998, 17, 3636; b) G. Jiménez Pindado, M. Thornton-Pett, M. B. Hursthouse, S. J. Coles, M. Bochmann, J. Chem. Soc. Dalton Trans. 1999, 1663; c) J. Sassmannshausen, A. K. Powell, C. E. Anson, S. Wocadlo, M. Bochmann, J. Organomet. Chem. 1999, 592, 84; d) P. J. W. Deckers, A. J. van der Linden, A. Meetsma, B. Hessen, Eur. J. Inorg. Chem. 2000, 929.

[13] C. Pellecchia, A. Immirzi, A. Grassi, A. Zambelli, Organometallics 1993, 12, 4473 .

[14] a) J. Scholz, M. Schlegel, K.-H. Thiele, Chem. Ber. 1987, 120, 1369; b) A. D. Horton, J. H. G. Frijns, Angew. Chem. 1991, 103, 1181; Angew. Chem. Int. Ed. Engl. 1991, 30, 1152.

[15] a) K. Shelly, D. C. Finster, Y. J. Lee, W. R. Scheidt, C. A. Reed, J. Am. Chem. Soc. 1985, 107, 5955; b) M. Laguna, M. D. Villacampa, M. Contel, J. Garrido, Inorg. Chem. 1998, 37, 133; c) A. S. Batsanov, S. P. Crabtree, J. A. K. Howard, C. W. Lehmann, M. Kilner, J. Organomet. Chem. 1998, 550, 59.

[16] P. Royo, J. Cano, M. A. Flores, EP 01500020.12001

[17] G. M. Sheldrick, SHELXL-97, Program for the Solution and the refinement of Crystal Structures, Universität Göttingen, Germany, 1997.

\section{Tetrathiafulvaleno-Annelated Porphyrins***}

Jan Becher,* Thomas Brimert, Jan O. Jeppesen, Jens Z. Pedersen, Roman Zubarev, Thomas Bjørnholm, Niels Reitzel, Torben R. Jensen, Kristian Kjaer, and Eric Levillain

\section{Dedicated to Professor Michael P. Cava \\ on the occasion of his 75 th birthday}

Porphyrins are of fundamental importance in biological systems and are currently in focus for applications in supramolecular ${ }^{[1]}$ and materials chemistry, for which the porphyrin chromophore has been extensively modified to enhance the desired properties. ${ }^{[2]}$ Langmuir-Blodgett (LB) films ${ }^{[3]}$ of porphyrin derivatives have been studied because of their optical, magnetic, and electrical properties. ${ }^{[4]}$ Tetrathiafulvalene (TTF) is able to exist in three different stable redox states (TTF, $\mathrm{TTF}^{+}$, and $\mathrm{TTF}^{2+}$ ). For this reason TTF derivatives have found widespread use ${ }^{[5]}$ in materials chemistry. Since the first TTF charge-transfer complex with metallic behavior was reported $^{[5 a]}$ a huge number of TTF radical-cation salts have been studied resulting in the discovery of organic superconductivity in some of these systems. ${ }^{[5 a]}$ Although there have been some attempts to combine TTF chemistry with porphyrin chemistry, the direct combination of these two major fields has so far been unsuccessful, most likely on account of the lack of an appropriate pyrrolo-TTF unit. Some of us recently developed an efficient synthesis of the parent pyrrolo[3,4- $d]$ TTF ring system using a nonclassical and simple pyrrole synthesis. ${ }^{[6]}$ With this building block at hand, we decided to prepare the first examples of single molecules in which the intriguing optical and metal-ion binding properties of the

[*] Prof. J. Becher, Dr. T. Brimert, M. Sc. J. O. Jeppesen, Dr. J. Z. Pedersen, Prof. R. Zubarev

Department of Chemistry

Odense University (University of Southern Denmark)

Campusvej 55, 5230, Odense M (Denmark)

Fax: $(+45) 66-15-87-80$

E-mail: jbe@chem.sdu.dk

Prof. T. Bjørnholm, N. Reitzel

Nano-Science Center, Department of Chemistry

University of Copenhagen

Universitetsparken 5, 2100, Copenhagen $\varnothing$ (Denmark)

Dr. T. R. Jensen, Dr. K. Kjaer

Condensed Matter Physics and Chemistry Department

Ris $\varnothing$ National Laboratory

Building 108, Post Office Box 49, 4000 Roskilde (Denmark)

Dr. E. Levillain

Ingénierie Moléculaire et Matériaux Organiques

CNRS UMR 6501, Université d'Angers, 49045 Angers (France)

[**] We gratefully acknowledge financial support from Carlsbergfondet and Bengt Lundquists Minnesfond for a post-doctoral position to T. B., the University of Odense for a Ph.D. scholarship to J. O. J. and the French Embassy Copenhagen for a travel grant to J. B. We thank HASYLAB at DESY, Hamburg for beam time at beam line BW1 and DANSYNC for financial support. The gift of Jan Skov Peterson's FORTRAN program LSQREFL is gratefully acknowledged. Finally, we thank Prof. K. S. Murray, University of Monash, Australia for helpful discussions.

Supporting information for this article is available on the WWW under http://www.angewandte.com or from the author. 